\title{
Rosa Bruno-Jofré, James Scott Johnston, Gonzalo Jover, and Daniel Tröhler Democracy and the Intersection of Religion and Traditions: The Reading of John Dewey's Understanding of Democracy and Education
}

Montreal: McGill-Queen's University Press, 2010. 176 pp.

\section{Harro Van Brummelen}

Trinity Western University

On an airline flight both a thoughtful Muslim businessman and a flight attendant were captivated by the title of this book, particularly by its promise to explore the interaction of democracy and religion. My expectation that the book will, however, disappoint them is not a reflection of the book's quality, but, rather, that the book's subtitle is more descriptive of its contents than its main title.

The book's authors convincingly demonstrate how educational thinkers and leaders worldwide have more often than not interpreted and reconfigured John Dewey's views to suit their own particular ideologies. They interpreted, mediated and synthesized Dewey's notions of democracy and progress with their own understanding of their historical, cultural, and social contexts.

James Scott Johnston explores the effects of Dewey's two-year sojourn in China (1919-1921). Chinese educators, including a former student of Dewey, Hu Shih, used Dewey to further their own agendas, even changing the meaning of Dewey's lectures as they translated them into Chinese. Dewey believed that true democracy would come about only if China took responsibility for its own transformation, using the strengths of its cultural heritage: "It is the public itself that must decide whether to develop and follow democratic practices" (67). However, Hu Shih and others during the "May 4th movement of 1919" tried to impose Western individualism, pragmatism, scientific ideals as well as Western democratic practices on Chinese culture. At least in part because of the misrepresentation of Dewey's views, while China did 
adopt certain scientific ideas and models, the democratic ideals that Dewey propounded did not take root. Johnston concludes that "there can be no possibility of democratic education unless a public has a genuine need or interest in developing such an education" (68).

In the next chapter Gonzalo Jover argues that early in the twentieth century key educators in Spain promoted Dewey's pedagogy, his learning by doing, without its pragmatic philosophical underpinnings or his social and democratic aims. Domingo Barnés, for instance, emphasized that Dewey's learning by doing ought to prepare students for life in society, but separated his pedagogy from its pragmatic roots by holding that values and ethics must be seen in an ideal rather than in an empirical sense. Similarly, Lorenzo Luruziaga held that Dewey's pedagogy correctly saw schools in terms of "activity, vitality, and acknowledgement of childhood personality" (96), but, unlike Dewey, did not believe that this would lead to schools enabling socialpolitical growth. Jover concludes that "Dewey's ideas resonated in Spain because they agreed with the aspirations of the times" (104) and built on prior accepted views of pedagogy such as that of Froebel.

Rosa Bruno-Jofrés contribution is the only one that focuses specifically on the intersection of Dewey's views and religion. She explores how liberal Protestant Christian missionaries in Latin America coopted Dewey's notions of democracy and progress for their own purposes. The overall missionary project integrated radical social gospel ideals with Dewey's educational theories - the same stream of thought that has influenced the left wing of Canadian politics from J. S. Woodsworth to Jack Layton. Dewey's learning through experience was stressed, but his conception of democracy was transformed into a liberal Protestant view which, contrary to Dewey, included the imposition of liberal Protestant religion and morality as well as American-style civil order as universal functions of life.

Daniel Tröhler, in the book's first chapter, describes how John Dewey believed that educating for democracy could address the social problems that he observed. Here Tröhler's posited interpretive framework is that Dewey's thinking is an expression of the liberal and secular pragmatic Protestantism directing American dispositions. He is only partly convincing, perhaps because of the chapter's brevity in analyzing Dewey's educational theory. While America's liberal Protestantism did embrace education as a means of progress, Dewey's "religious convictions" as expressed, for instance, in Dewey's My Pedagogic Creed are anchored in a pragmatism that rejects Protestantism and promotes an areligious worldview perspective. For Dewey, the "true God" was a secular social order brought about through self-direction based on continuous reconstruction of experience. Dewey's desertion of his liberal Protestant roots can also be inferred from his close involvement with the original Humanist Manifesto.

That is not to say that the basic theme of this book is not soundly grounded: Dewey's views on education and society have been modified and applied by individuals and groups to suit their own worldviews and contexts. My first exposure to Dewey's ideas occurred when, as a newly arrived immigrant, my grade 6 teacher used the so-called progressive "enterprise method" to structure experiential learning. Yet, while using Deweyan pedagogical strategies, she also anchored her curriculum in a 
conservative Christian faith and morality complemented with strong loyalty to the British crown as the symbol of true liberty and civic virtue. In short, as this book's authors demonstrate, educational thinkers have frequently mediated Dewey's philosophy of education to suit particular contexts. And, no doubt, classroom teachers have just as frequently followed suit. 